\title{
The Effectiveness of Anger Management Training on Decreasing the Anger of Unsupervised Girl Adolescents
}

\author{
Tayebeh Mokhber ${ }^{1}$, Abbas Masjedi2 ${ }^{*}$, Maryam Bakhtiari² \\ ${ }^{1}$ MSc of Clinical Psychology, Faculty of Medicine, Shahid Beheshti University of Medical Sciences, Tehran, Iran \\ ${ }^{2}$ Assistant Professor of Clinical Psychology, Faculty of Medicine, Shahid Beheshti University of Medical Sciences, Tehran, Iran \\ Email: ^doctormasjedi@yahoo.com
}

How to cite this paper: Mokhber, T., Masjedi, A. and Bakhtiari, M. (2016) The Effectiveness of Anger Management Training on Decreasing the Anger of Unsupervised Girl Adolescents. Open Journal of Medical Psycho$\log , 5,66-71$.

http://dx.doi.org/10.4236/ojmp.2016.54008

Received: August 31, 2016

Accepted: September 27, 2016

Published: September 30, 2016

Copyright $\odot 2016$ by authors and Scientific Research Publishing Inc. This work is licensed under the Creative Commons Attribution International License (CC BY 4.0). http://creativecommons.org/licenses/by/4.0/

\begin{abstract}
This study aims to study the effectiveness of anger management training on decreasing anger of unsupervised girl adolescents aged 15 - 18 years old of Tehran. This research was an experimental one with plan of pre-test-post-test control group. The statistical universe of this research consisted of all unsupervised girl adolescents aged 15 - 18 years old of Tehran. The sample was 24 unsupervised girl adolescents identified from girls assigned to the two groups: experimental group and control group. Data were collected using the State-Trait Anger Expression Inventory (STAXI-2). Analysis of variance with repeated measure showed that the anger management training significantly decreased anger in the experimental group $(\mathrm{P}<0.01)$. This finding has important implications as regards the education and mental health of adolescents.
\end{abstract}

\section{Keywords}

Anger Management Training, Anger, Unsupervised Adolescents

\section{Introduction}

Adolescence is a unique time in life [1] and one of the most challenging periods of growth and change is human growth [2]. Therefore, it imposes unwanted pressure on young people and provides them with social disabilities, making a deep and emotional faces [3]. That is why in recent years, questions about the nature of normal and abnormal growth in adolescence have special significance [4]. The experts believe that at the warm and friendly family environment where parents and other family members and intimate relations are good, children usually bring healthy and positive personality [5]. 
Unfortunately, in today's society with rising divorce rate, drug addiction, poverty, etc. which are the consequence of industrialization of societies, derelict phenomenon and the number of children orphaned significantly increase [6] [7]. The prevalence of mental health problems among children and adolescents in different countries from $3 \%$ to $24 \%$ has declared [8]. According to theoretical foundations, more than a fifth of children suffer from at least one mental health problem [9] [10]. In addition, the daily routine and ordinary families, their relationships and conflicts as resources on the growth of the offspring increased [11] [12] [13] [14].

The study results in this field indicated the effectiveness of anger management training on reducing aggression [15], increasing compatibility and social skills [16], and increasing insight [17] [18]. The aim of this study was to evaluate the effectiveness of anger control on unsupervised girl's anger.

\section{Material and Methods}

This research method is experimental with pretest-posttest control group. The study population consisted of all unsupervised girls of 18 - 15 years in Tehran in 2014. The study inclusion criteria were age 15 to 18 years, at least one parent is enough inefficiency, lack of psychological disorders. Exclusion criteria included psychiatric and therapeutic intervention psychological and at the same time, the absence of more than three days and not wanting to participate in the training group sessions. The following tools were used to collect data.

Trait Anger Inventory-Spielberger state (STAXI-2): This questionnaire has 57 female subjects felt strongly based on multiple choice scale from "Not at all = 1" to "extremely = 4" are determined. The scale includes the scale of the anger mode (S-Ang), trait anger (T-Ang) anger (AX-O), Anger (AX-I), controlling anger (AC-O), and controlling anger (AC-I). Alpha reliability coefficient of the questionnaire scales and subscales of trait anger and anger overseeing the case against the 0.84 or higher and for measures governing the expression of anger, anger control and express anger of the overall index is greater than or equal to 0.73 [19]. Khodayarifard et al. examined the validity of the test and were approved by qualified personnel.

In this study using Cronbach's alpha reliability coefficient for trait anger and rage mode 0.93 and 0.83 respectively, it express anger and expressing anger, respectively, 0.60 and 0.73 and 0.89 and 0.87 to control anger and anger control is obtained [20].

After the questionnaires of pre-test, the anger management training of experimental group according to Table 1 (in 12 sessions of 60 minutes) was presented. It should be noted that the control group received no intervention. After the training, as post-test questionnaires and six weeks later in order to track the results were implemented.

\section{Results}

According to the results, the highest percentage of respondents is in the age group of 15 years ( 40 percent) and the lowest percentage of respondents ( 14.3 percent) is in the age group 18 and 17 years old. 
Table 2 shows mean and standard deviation of anger in unsupervised girl adolescents in groups based on pretest, posttest and follow-up.

Table 1. Anger management and social skills training groups.

First session: Meet the members of the group, reviewing the goals of the group, rules group as well as conceptual and logical framework anger management therapy

Second Session: Learn how to analyze the course of his anger, identify events and marks the beginning of anger, listing specific events trigger anger in people and finding different events and interpretation of events

Third session: training cognitive behavioral strategies control anger immediate and preventive training and relaxation through breathing interruptions strategies

Fourth Session: Training courses aggression that included a three-stage start-export and post-export is also progressive muscle relaxation session ended with the training and use of technology

Fifth Session: A-B-C-D model of education as cognitive restructuring and fans stop thinking model

Sixth Session: Review concepts learned, review homework

Seventh and eighth sessions: skills training assertiveness, aggression, passivity and conflict resolution model

Ninth and tenth sessions: Effect of past learning on current behaviors

Eleventh Session: Review concepts learned, encouraged in order creating balance in the use of cognitive behavioral strategies, immediate and proactive

Twelfth Session: Browse by members of anger management programs; summary and post-test performance

Table 2. Means and Standard Deviation (SD) of anger in the control and experiment group.

\begin{tabular}{|c|c|c|c|}
\hline \multirow{2}{*}{ Variables } & \multirow{2}{*}{ Stages } & Control Group & Anger Management Training \\
\hline & & $\mathrm{M} \pm \mathrm{SD}$ & $\mathrm{M} \pm \mathrm{SD}$ \\
\hline \multirow{3}{*}{ S-Ang } & Pre-test & $35.24 \pm 6.21$ & $36.50 \pm 6.82$ \\
\hline & Post-test & $33.34 \pm 5.53$ & $20.91 \pm 4.31$ \\
\hline & Follow-up & $34.27 \pm 5.24$ & $27 \pm 6.39$ \\
\hline \multirow{3}{*}{ T-Ang } & Pre-test & $31.78 \pm 3.10$ & $32.08 \pm 4.64$ \\
\hline & Post-test & $30.58 \pm 4.53$ & $20.08 \pm 4.12$ \\
\hline & Follow-up & $31.49 \pm 5.83$ & $24.25 \pm 4.07$ \\
\hline \multirow{3}{*}{$\mathrm{AX}-\mathrm{O}$} & Pre-test & $28.57 \pm 3.52$ & $27.50 \pm 2.87$ \\
\hline & Post-test & $28.64 \pm 3.70$ & $18.75 \pm 4.22$ \\
\hline & follow-up & $29.56 \pm 2.83$ & $23.16 \pm 2.85$ \\
\hline \multirow{3}{*}{ AX-I } & Pre-test & $25.43 \pm 3.87$ & $27.41 \pm 3.23$ \\
\hline & Post-test & $24.53 \pm 3.24$ & $18.91 \pm 3.91$ \\
\hline & Follow-up & $24.12 \pm 4.52$ & $23.83 \pm 3.06$ \\
\hline \multirow{3}{*}{ AC-O } & Pre-test & $18.98 \pm 4.10$ & $17.75 \pm 3.27$ \\
\hline & Post-test & $17.68 \pm 2.79$ & $28.33 \pm 3.55$ \\
\hline & Follow-up & $18.24 \pm 3.83$ & $23.58 \pm 4.12$ \\
\hline \multirow{3}{*}{ AC-I } & Pre-test & $23.24 \pm 4.12$ & $21.25 \pm 2.73$ \\
\hline & Post-test & $24.12 \pm 3.34$ & $30.25 \pm 3.95$ \\
\hline & Follow-up & $24.32 \pm 2.75$ & $24 \pm 2.89$ \\
\hline
\end{tabular}


According to Table 3, it shows Mauchly's normality multivariate statistics. As a result of this default table for variables state anger, trait anger and anger control with a significance level of less than 0.05 cannot be verified $(\mathrm{P}<0.05)$. Therefore, to moderate degree of freedom to interpret the $\mathrm{F}$ Internal testing is required and for variables anger, anger and anger control is verified at a significance level greater than $0.05(\mathrm{P}<0.05)$. So to moderate degree of freedom to interpret the $\mathrm{F}$ Internal testing is required.

Table 4 shows the results of variance analyses as follows: anger, $F_{-}((1,11))=7.79$, trait anger, with $\mathrm{F}_{-}((1,11))=34.77$, outer anger with $\mathrm{F}_{-}((2,22))=25.61$, inner anger, with $F_{-}((2,22))=20.87$, control anger, with $F_{-}((2,22))=19.78$, control anger, with F_ $((1,11))=21.36$ and P: 0.001 .

As a result, a state of anger control training in reducing mode anger, trait anger, outer anger, inner anger, anger management and control in unsupervised girls have been effective in Tehran. To determine if there is a significant difference between the three steps between which a Bonferroni post hoc test results are given in Table 5.

Table 3. Mauchly's sphericity test results, to comply with repeated measures ANOVA default.

\begin{tabular}{ccccc}
\hline Within Subjects Effect & Mauchly's W & Approx. Chi-Square & $\mathrm{df}$ & $\mathrm{P}$ \\
\hline S-Ang & 0.47 & 7.44 & 2 & 0.024 \\
T-Ang & 0.53 & 6.30 & 2 & 0.043 \\
AX-O & 0.80 & 2.22 & 2 & 0.32 \\
AX-I & 0.76 & 2.66 & 2 & 0.26 \\
AC-O & 0.88 & 1.28 & 2 & 0.52 \\
AC-I & 0.30 & 11.98 & 2 & 0.002 \\
\hline
\end{tabular}

Table 4. Results of within-subjects analysis of variance (lower-bound) for the variable anger in the experimental group.

\begin{tabular}{ccccccc}
\hline & Variables & SS & df & F & Sig & Partial Eta Squared \\
\hline \multirow{2}{*}{ S-Ang } & Lower-bound & 1480.38 & 1 & 22.29 & 0.001 & 0.67 \\
& Error & 714.27 & 11 & & & \\
T-Ang & Lower-bound & 890.88 & 1 & 34.77 & 0.001 & 0.76 \\
& Error & 281.77 & 11 & & & 0.70 \\
AX-O & lower-bound & 459.38 & 2 & 25.61 & 0.001 & \\
& Error & 197.27 & 22 & & & 0.65 \\
AX-I & Lower-bound & 437.05 & 2 & 20.87 & 0.001 & 0.64 \\
& Error & 230.27 & 22 & & & \\
AC-O & Lower-bound & 674.38 & 2 & 19.78 & 0.001 & \\
& Error & 374.94 & 22 & & & \\
AC-I & Lower-bound & 510.50 & 1 & 21.36 & 0.001 & \\
\hline
\end{tabular}


Table 5. Bonferroni post hoc test for multiple comparisons of anger in three phases.

\begin{tabular}{|c|c|c|c|c|c|}
\hline Variable & & & $(\mathrm{I}-\mathrm{J})$ & Std. Deviation & Sig \\
\hline \multirow{3}{*}{ S-Ang } & \multirow{2}{*}{ Pre test } & Post test & 15.58 & 1.98 & 0.001 \\
\hline & & Follow-up & 9.50 & 3.04 & 0.029 \\
\hline & Post test & Follow-up & -6.08 & 1.73 & 0.015 \\
\hline \multirow{3}{*}{ T-Ang } & \multirow{2}{*}{ Pre test } & Post test & 12 & 0.93 & 0.001 \\
\hline & & Follow-up & 7.83 & 1.84 & 0.004 \\
\hline & Post test & Follow-up & -4.16 & 1.45 & 0.046 \\
\hline \multirow{3}{*}{$\mathrm{AX}-\mathrm{O}$} & \multirow{2}{*}{ Pre test } & Post test & 8.75 & 1.14 & 0.001 \\
\hline & & Follow-up & 4.33 & 1.01 & 0.004 \\
\hline & Post test & Follow-up & -4.41 & 1.46 & 0.035 \\
\hline \multirow{3}{*}{ AX-I } & \multirow{2}{*}{ Pre test } & Post test & 8.50 & 1.60 & 0.001 \\
\hline & & Follow-up & 3.58 & 1.18 & 0.035 \\
\hline & Post test & Follow-up & -4.91 & 1.11 & 0.003 \\
\hline \multirow{3}{*}{ AC-O } & \multirow{2}{*}{ Pre test } & Post test & -10.58 & 1.45 & 0.001 \\
\hline & & Follow-up & -5.83 & 1.94 & 0.036 \\
\hline & Post test & Follow-up & 4.75 & 1.61 & 0.040 \\
\hline \multirow{3}{*}{ AC-I } & \multirow{2}{*}{ Pre test } & Post test & -9.00 & 1.54 & 0.001 \\
\hline & & Follow-up & -2.75 & 0.62 & 0.003 \\
\hline & Post test & Follow-up & 6.25 & 1.78 & 0.015 \\
\hline
\end{tabular}

\section{Discussion}

This study aimed to determine the effectiveness of training method in anger control on unsupervised girl's anger. In other words, average grades and modes of anger, in the experimental groups rather than the control group, had increased substantially. And people who receive cognitive-behavioral approach to anger management training, using the techniques of cognitive restructuring, are more capable to control anger. In this way and in line with these results, study of Piligniroo (2012) showed that training based on cognitive-behavioral therapy reduced anger and problems arising from lack of control in high school students and increased insight and awareness of it [17].

\section{References}

[1] Safavi, M., Yahyavi, S.H. and Poorrahimi, M. (2012) Effect of Dietary Behaviours and Physical Activity Self-Efficacy Training School Students. Islamic Azad University Journal of Medical Sciences, 22, 151-143.

[2] Kathleen, M.L., Esecott-Stump, S., Eds. (2004) Krouse's Food Nutrition and Diet Therapy. 11th Edition, Pennsylvania: Elsevier, Philadelphia, 150-192.

[3] Ruttle, P.L., Shirtcliff, E.A., Serbin, L.A., Fisher, D.B.D., Stack, D.M. and Schwartzman, A.E. (2011) Disentangling Psychobiological Mechanisms Underlying Internalizing and Externalizing Behaviors in Youth: Longitudinal and Concurrent Associations with Cortisol. Hormones and Behavior, 59, 123-132. http://dx.doi.org/10.1016/j.yhbeh.2010.10.015

[4] Steinberg, L. (2005) Cognitive and Affective Development in Adolescence. Trends in Cognitive Sciences, 9, 69-74. 
[5] Keisha, L., Deneia, T., et al. (2009) Influence of Multiple Attachments on Well-Being: A Model for African Americans Attending Historically Black Colleges and Universities. Journal of Diversity in Higher Education, 2, 35-45. http://dx.doi.org/10.1037/a0012651

[6] Hoksbergen, R.A.C. and Terlak, Y. (2003) Post Traumatic Stress Disorder in Adopted Children. American Journal of Ortho Psychiatry, 73, 255-265. http://dx.doi.org/10.1037/0002-9432.73.3.255

[7] Zadeh Mohamadi, A., Sadressadat, S.J. and Birashk, B. (2006) The Effect of Active Music Therapy in Reducing Behavioral and Emotional Disorders. Psychology Journal, 10, 222231.

[8] Mohammadi, M., Bagheriyazdi, S., et al. (2003) Epidemiological Study of Psychiatric Disorders in Tehran Province. Iranian Journal of Psychiatry and Clinical Psychology, 9, 4-14.

[9] Cuner-Kucukkaya, P. (2010) Predictors of Psychiatric Symptom Scores in a Sample of Turkish High School Students. Nursing \& Health Sciences, 12, 429-436. http://dx.doi.org/10.1111/j.1442-2018.2010.00553.x

[10] Meunier, J.C., Roskam, I., Stievenart, M., Moortele, G., Browne, D.T. and Kumar, A. (2011) Externalizing Behavior Trajectories: The Role of Parenting, Sibling Relationships and Child Personality. Journal of Applied Developmental Psychology, 32, 20-33. http://dx.doi.org/10.1016/j.appdev.2010.09.006

[11] Fiese, B.H. and Winter, M.A. (2010) Family Influences. Encyclopedia of Infant and Early Childhood Development, 492-501.

[12] Nelson. M. (2010) Psychiatric Mental Health Nursing. Wiley \& Sons, New York, 556.

[13] Association, A.P. (2004) Controlling Anger before It Controls You.

[14] Disqiuseppe, R.C. (2003) Aggression in Adolescents. Journal of Clinical Psychology, 10, 254-260.

[15] Maleki, S., Rahgooi, A. and Rahgozar, M. (2011) The Effect of Anger Management Training in Groups on Aggression of 12 - 15 Years Old Male Students. Iran Journal of Nursing, 24, 26-35.

[16] Dortaj, F. and Asadzadeh, H. (2010) The Effect of Anger Management Training on Aggression and Social Adjustment of 12- 15 Years Old Male Students. Journal of Applied Psychology, 3, 62-72.

[17] Pellegrino, B. (2012) Evaluating the Mindfulness-Based and Cognitive-Behavior Therapy for Anger Management Program. PhD Dissertation, Philadelphia College of Osteopathic Medicine.

[18] Comer, J.S., Chow, C., Chan, P.T., Cooper-Vince, C. and Wilson, L.A.S. (2013) Psychosocial Treatment Efficacy for Disruptive Behavior Problems in Very Young Children: A Meta-Analytic Examination. Journal of the American Academy of Child and Adolescent Psychiatry, 52, 26-36. http://dx.doi.org/10.1016/j.jaac.2012.10.001

[19] Spielberger, C.D., Johnson, E.H., Russell, S.F., Crane, R.J., Jacobs, G.A. and Worden, T.J. (1985) The Experience and Expression of Anger: Construction and Validation of an Anger Expression Scale. 5-30.

[20] Khodayari Fard, M., Gholam Ali Lavasani, M., Akbari Zardkhane, S. and Liaghat, S. (2007) Evaluating the Psychometric Properties and Standardized of State-Trait Anger Expression Inventory (STAXI) among Students of Tehran University. University of Tehran, Tehran. 
Submit or recommend next manuscript to SCIRP and we will provide best service for you:

Accepting pre-submission inquiries through Email, Facebook, LinkedIn, Twitter, etc. A wide selection of journals (inclusive of 9 subjects, more than 200 journals)

Providing 24-hour high-quality service

User-friendly online submission system

Fair and swift peer-review system

Efficient typesetting and proofreading procedure

Display of the result of downloads and visits, as well as the number of cited articles

Maximum dissemination of your research work

Submit your manuscript at: http://papersubmission.scirp.org/

Or contact ojmp@scirp.org 